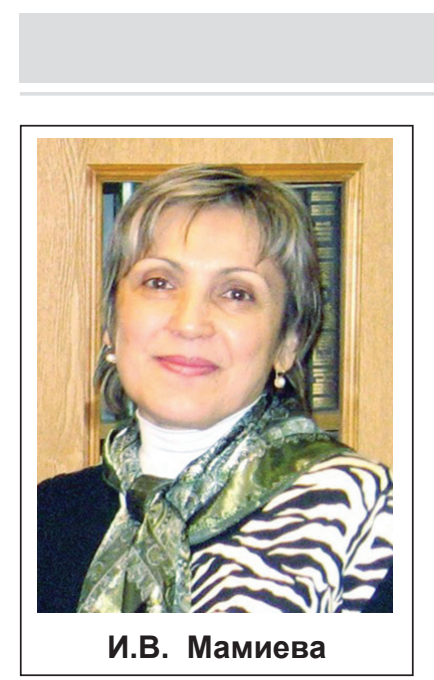

\title{
ИВАН ЯЛГУЗИДЗЕ (ИУАНЕ ГАБАРАЕВ) - ПРЕДТЕЧА ГОРСКОГО ПРОСВЕТИТЕЛЬСТВА
}

\author{
И.В. Мамиева*
}

\begin{abstract}
Аннотация. В статье рассмотрены этапы и аспекты личностного и творческого становления видного осетинского деятеля конца XVIII - первой трети XIX века И. Габараева (Ялгузидзе) с целью последовательного обоснования факта его первопроходства в важнейших сфрерах просветительского движения на Северном Кавказе. Отмечается ряд разночтений в биографических сведениях, вносятся некоторые коррективы и уточнения. Дается анализ корпуса просветительских текстов, в которых особый акцент сделан на автобиографическом нарративе как своде императивов, формирующих тип просветительской личности.

Ключевые слова: И. Габараев-Ялгузидзе, просветитель, педагог, православный миссионер, переводная литература, деловая документалистика, письменность, автобиографрический нарратив, элемент художественности, национальная идентичность.
\end{abstract}

В просветительском движении, возникшем на Северном Кавказе в очень сложных социально-политических условиях в конце XVIII - первой трети XIX века, в начальный период преобладали идеи, связанные с пропагандой знаний, культурного развития горских народов, глубины осмысления ими своего будущего, ставились вопросы разумной коррекции проблем общественного бытия, утверждался культ разума в целом. При характеристике горского просветительства как общетипологического явления следует оговорить тот фракт, что у народов Северного Кавказа и Дагестана, исповедующих ислам, наряду с просветительской концепцией развития общества и человека, значительную роль в выработке культурно-эстетических воззрений сыграли джадидизм («мусульманская реформация») и религиозная литература на арабском языке [1, с. 4]. В Осетии в означенное время доминирует влияние православной духовной практики. И потому просветительская доминанта здесь в первую очередь - свет Божественной истины. Первая печатная осетинская книга так и называлась - «Начальное учение человеком, хотящим учитися книг божественного писания» (1798).

У истоков уникального историко-культурного феномена на Северном Кавказе стоит Иван Георгиевич Ялгузидзе (Гæбæраты Иуане) (1775-1830). Но в огромном множестве региональных исследований, в том числе и осетинских, данное обстоятельство обходят молчанием. Исключение составляет учебное пособие Е.Е. Хатаева «Просветители горских народов XIX века», где наш соотечественник представлен как «зачинатель просветительского движения среди горских народов Северного Кавказа», но без какой-либо аргументации в пользу этого утверждения [2, с. 12-13].

Цель настоящей статьи - сформировать доказательную базу для обоснования первопроходства И. Ялгузидзе ${ }^{1}$ на поприще северокавказского просветительства.
Биографические сведения. Годы учебы. О вехах жизни и деятельности Иуане ГабараеваЯлгузидзе - просветителя, педагога, православного миссионера, автора литературных произведений, истинного интеллигента духа - мы можем судить по редким архивным документам, в основном же благодаря оставленным им самим свидетельствам. Это - автобиография на грузинском языке (1820) и Предисловие к переводу Четвероевангелия (1823) на осетинском языке. Из автобиографических заметок мы узнаем удивительную историю мальчика из небольшого горного селения Залда Горийского уезда (ныне Цхинвальского района Южной Oceтии), волею провидения удостоенного покровительства царя Грузии, Ираклия II. Получив благодаря тому хорошее для своего времени образование, он использовал его во благо родного народа, одарив осетин Книгой - источником знания и духовного обогащения.

Значимый вклад в реконструкцию биографических данных Иуане Габараева внесли Н. Гамрекели, К. Кекелидзе, Г. Ахвледиани, Г. Бочоридзе, Дз. Гугкаев и др. Недавно появилось научно-популярное издание Л.А. Чибирова, в котором «в хронологическом диапазоне со второй половины XIX в. до наших дней» [3, с. 9] обобщены итоги изучения жизни и творчества просветителя, этой замечательной во всех отношениях личности, ставшей для Осетии подлинным даром судьбы.

Следует признать, однако, что биографы И. Габараева, активно обращаясь к архивным и автобиографическим материалам, некоторые противоречия в них принимают неконфликтно (касательно, например, личного участия царя Грузии Ираклия II в судьбе будущего просветителя, этапов его обучения и пр.), а нередко и сами вносят путаницу в хронологию эпизодов и событий жизни просветителя. Биографические разночтения можно списать на непростую историю введения документальных источников в научный оборот. Как известно, рукопись автобиографии Ялгузидзе была обнаружена в го-

" Мамиева Изета Владимировна - к. фр. н., доцент, старший научный сотрудник СОИГсИ (dzirasga@mail.ru).

${ }^{1}$ Ялгузидзе - огрузиненное написание древнего осетинского рода АЕъуызатæ, одной из ветвей которого является фрамилия Габараевых. 
сударственном архиве Грузии, в фронде канцелярии экзархата (ЦГИА Грузии, ф. 488, д. 488, л. 109-112). Возможность ознакомиться с оригинальной версией в полном объеме исследователям представилась лишь в 1985 г., благодаря фраксимильной копии в книге О. Тедеевой, исследующей язык первых осетинских рукописей [4, с. 110]. Автограф перевода Евангелия с предисловием к нему - находка известного русского востоковеда Карла Германовича Залемана (1849-1916), который транслитерировал предисловие с грузинской на осетинскую графику и параллельно со своим переводом на немецкий язык опубликовал в сборнике статей Российской Академии наук «Азиатская всячина» (Melanges Asiatiques) [5, с. 283-284]. Возможно, «неувязки» в автобиографических сведениях в какой-то степени исходят и от самого Ялгузидзе, но с не меньшей вероятностью, как нам кажется, они могут быть также результатом некачественного исследовательского «считывания» информации с грузинского языка.

Из имеющихся переводных версий указанной автобиографии следует, что Иуане «малолетним ребенком» был вывезен в Грузию, и здесь царь Ираклий II, узнавши о его благородном происхождении, дал наказ определить его в монастырь Иоанна Крестителя с тем, чтобы обучить чтению церковных книг на грузинском языке [6, с. 322]. В Предисловии же речь идет о том, что в Грузию Иуане был привезен («приведен») самим иарем, который и определил его в монастырь (выделено мною. М. И.). («Мыггаг æмæ цæуæтæй ироны, къаннæг сывæллоны мæ æркодта мæн Гуырдзыстоны мæликк Ерекъле дыккаг æмæ мæ радта мæн чиныг ахуыргæнæнмæ иттæг зæрдæйæ. Ацы фрæндæй, æмæ кæд сымах, ме 'мирон мыггагæн, йæ афроныл истæмæй бæззон, ахъазхъом фрæцаин») ${ }^{2}$ [7, с. 98] Думается, слова просветителя едва ли следует воспринимать буквально, скорее всего, имелось в виду, что в Грузию его привезли по распоряжению царя, который известен в истории как прогрессивная личность. «В период его царствования некоторые из осетинских детей, родители которых принадлежали привилегированной социальной верхушке, брались для подготовки из них грамотных церковнослужителей, способных распространять и укреплять христианство среди своих соотечественников» [6, с. 283].

В ряде исследовательских трудов со ссылкой на источник 1901 года [8, с. 101-102] и на «Историю грузинской литературы» К. Кекелидзе утверждается, что юноша воспитывался «при дворе царей Ираклия II и Георгия» [9, с. 282; 3, с. 19-20 и пр.], после чего его определили в Иоанна Крестителя монастырь «для обучения грузинской словесности» [3, с. 20]. Но обратимся к хронологии жизни царственной династии. 11 января 1798 года умер Ираклий II, и на трон заступил Георгий XII, послед- ний царь Грузии, правление которого было недолгим, он скончался 28 декабря 1800 года. Если верить вышеприведенным высказываниям, то Иуане Ялгузидзе «воспитывался при царском дворе», по крайней мере, до 23 лет и только затем был определен в монастырь Иоанна Крестителя, а следом - в Давидо-Гареджийскую пу́стынь, на обучение к священнику И. Карумидзе как знатоку фрилософиии [6, с. 322]. Но фракты говорят о другом. В Актах археографической комиссии есть задокументированное свидетельство - «Донесение Цилканского архиепископа Иоанна католикосу Антонию, на Высочайшее имя Г[осударя] И[мператора] Павла І», датированное 1 марта 1800 года, в котором о. Иоанн (И. Карумидзе) сообщает о том, что, по исполнении Иуане восьми лет или около того ( 1783 г.), мальчик по указу царя Ираклия был «пожалован» ему в Давидо-Гареджийскую пу́стынь с тем, чтобы обучить его «чтению, письму и всей учености, каковое повеление государя моего и было мною исполнено» [10, т. 1, с. 533]. Когда о. Иоанн был посвящен в архиереи и переведен в Цилканскую епархию, Иуане, «по приказанию царя», продолжал учиться у него, и «по прошествии некоторого времени» наставник представил своего подопечного августейшему монарху. По свидетельству самого Иуане, Ираклий II принял его милостиво и «изволил обещать дать довольное содержание». Однако неожиданная смерть царя лишила юношу возможности и в дальнейшем заручаться высоким покровительством [6, с. 322]. По всей видимости, Карумидзе успел привязаться к своему ученику, испытывал к нему уважение и симпатию, а потому продолжал заботиться о нем, определил его «в местечко Душет, собрав под его ведение 30 душ детей местных прихожан, для обучения их чтению и письму...». И даже содержал за свой счет [10, т. 1, с. 533].

Думается, постижение богословских и светских наук в Давидо-Гареджийской пу́стыни заняло у Иуане около 10 лет, до перевода его наставника на новое место работы, приблизительно в 1793 годуз3. Если это на самом деле так, то по окончании учебы юноше должно было исполниться не более 18 лет. И тут мы подходим к еще одной неуточненной дате - началу учительства Ялгузидзе. Во всех без исключения источниках читаем, что он проработал в Душети «пару лет» ( $1798-1801$ гг.) [3, с. 21; и др.]. Во всяком случае, в марте 1800 года, когда писалось цитируемое выше донесение Цилканского архиепископа католикосу Антонию, Иуане уже находился в указанной школе. Чем же в таком случае был заполнен отрезок времени между завершением образования в монастыре у Карумидзе и началом существования «на собственные средства» - а это приблизительно около 5 лет (1793-1798)? Волей-неволей всплывает в памяти фрраза, без которой редко какая статья нынче обходится: «По

\footnotetext{
2 Фонетические особенности южного говора в цитате не сохранены, но оставлена без изменения лексема «бæззон» (в знач. 'годный', ‘пригодный', ‘подходящий' - ср. сходную форму атрибутива у Коста: «Ныууадзмæ мæ адыл, / Фæндон хорз кæм и?!»), претерпевшая при публикации в разных источниках различные манипуляции.

${ }^{3}$ «Когда благочестивый царь всей Верхней Грузии, сын помазанного царя Теймураза, возымел желание вызвать меня (И. Карумидзе. - М. И.) из монастыря, <...> я был помазан архиерейским помазанием (назад тому 8-й год)» [10, m. 1, с. 532].
} 
непроверенным сведениям, окончил Тифрлисскую духовную семинарию». Но вслед за тем возникает и контрдовод: мог ли Ялгузидзе в известных нам авторезюме обойти молчанием столь существенный эпизод своей биографии? Чуть ниже мы еще вернемся к этому, пока же подытожим: окончил ли Иуане Тифлисскую духовную семинарию, продолжил ли обучение у Карумидзе или где-нибудь в другом месте, несомненно одно: он прошел серьезную по тому времени подготовку; помимо богословских наук изучал светские дисциплины, в том числе получал, как он сам пишет, «знания и по изящной словесности».

Деловая письменность. С присоединением Восточной Грузии к России (1801 г.) наступает новый этап в жизни И. Габараева (Ялгузидзе). Как писал генерал Паскевич, осетины «при первом появлении в сей стране российских войск... встретили их как своих избавителей» [10, т. VII, 359]. Когда же эти надежды не оправдались, повсеместно вспыхнули восстания против произвола грузинских помещиков, стремящихся с помощью русских властей закрепостить крестьян Южной Осетии. В этой сложной ситуации военно-гражданской администрации в Грузии потребовались кадры из местной интеллигенции, которые могли бы исполнять роль переводчиков и посредников в переговорах с непокорными горцами. И, как верно замечает Л.А. Чибиров, кандидатура Иуане оказалась здесь во всех отношениях безальтернативной [3, с. 2627]: во-первых, по причине его благородства и благовоспитанности; во-вторых, по знанию им языков, носителями которых являлись конфликтующие стороны; и в-третьих - благодаря известности и высокому авторитету Ялгузидзе в тифлисских кругах, в особенности же - среди сородичей, у которых он пользовался большим доверием «по кроткому его нраву и честности» [10, т. 1, с. 499].

И. Габараев (Ялгузидзе) был убежденным сторонником сближения с Россией, связывал с ней будущее осетинского народа. Прав Л.А. Чибиров: «Хотя официально он именовался переводчиком, но по докладным, которые составлял по возвращении в Тифлис, видно, что его обязанности были гораздо шире» [3, с. 27]. Свою миссию он видел в том, чтобы довести до осетин волю русского начальства, а до тех, в свою очередь, - чаяния и надежды осетинского трудового крестьянства. Это было внутренней, сокровенной целью его деятельности [11], так сказать, его сверхзадачей, сопряженной с идеей отдачи долга своему народу. Об этом свидетельствуют рапорты подполковнику Ф. Симоновичу, возглавившему в 1802 году первую экспедицию «по усмирению» восставших против произвола грузинских фреодалов осетин - жителей Паца, побережий Большой и Малой Лиахвы и Куры, а также НароМамисонской котловины.

Экземпляры деловой письменности (официальная и частная переписка с конца XVIII века сословных групп и частных лиц из Кабарды, Чечни, Дагестана, Осетии с представителями русской военной власти на Кавказе и с османской Турцией) в современных трудах относят к «документальной предыстории» просветительства [1, с. 9; 12, с. 164]. В этот разнохарактерный материал, оцениваемый специалистами как «рукописное литературное наследие», органично вписываются и прошения, составляемые И. Ялгузидзе для своих неграмотных сородичей [3, с. 16], а также упомянутые выше служебные донесения [9, с. 294-297].

Рапорты, адресованные командующему Кавказским гренадерским полком Ф. Симоновичу, представляют большой интерес в плане проявления личности автора, его гражданской позиции. В них критика феодальных порядков не только очевидна, она приобретает острую сатирическую направленность. «Служебный доклад, вследствие введенных в нарративный текст элементов чужого высказывания и их субъективной оценочности, трансформируется в колоритную жанровую сцену. Благодаря стихии устного слова повествование на чужом языке вбирает характерные интонации родной речи. В то же время оно пронизано дыханием авторской мысли, чувства и настроения» [13, с. 105].

Если учесть, что самое раннее из сочинений указанного типа - «Записки о беспорядках на Кавказской линии и способах прекратить оные» под авторством Измаил-бея Атажукина [1750?-1811?], одного из провозвестников адыгского просветительства, - датируется $\approx 1802$ годом, то получается, что и здесь наш соотечественник в авангарде. Заметим при этом, что официальные донесения Ялгузидзе значимы «не только в аспекте фрактографическом, но и в ракурсе "прорастания" в них элементов эстетического значения, когда факт, помимо своей прямой служебной функции, начинает нести функцию художественной образности» [13, с. 105].

Педагогическая деятельность Иуане, как сказано выше, начиналась в Душетской церковно-приходской школе, где он обучал крестьянских детей чтению и письму на грузинском языке. Не кажется убедительной информация Л.А. Чибирова о том, что «И. Габараев (Ялгузидзе) в 1802 г. был переведен в Тифлис, где в местной духовной семинарии преподавал грузинскую, русскую и осетинскую словесность» [3, с. 21]; во-первых, она документально ничем не подтверждена; во-вторых, из архивных источников и из слов самого просветителя известно, что с февраля по август 1802 года он неоднократно направлялся командиром Кавказского гренадерского полка подполковником Федором Симоновичем в ущелья Южной и Северной Осетии с целью «вразумления, успокоения» и приведения осетин к присяге на верность российской державе [10, т. І, с. 582-587]. И. Габараев (Ялгузидзе) пишет о том, что он был посылаем в самые трудные и опасные зоны противостояния горцев. Во многих местах перешел через Кавказские горы, даже через покрытый вечными ледниками перевал Зикара [6, с. 323]. Совместима ли столь интенсивная походная жизнь с преподавательской деятельностью, и не где-нибудь, а в Тифлисе? Думаем, что нет.

Лишь в феврале 1820 года, после 18-летнего перерыва, И. Ялгузидзе вновь вернется к препо- 
даванию, теперь уже в начальных классах приходского духовного училища при Тифрлисской духовной семинарии, где до января 1822 г. будет воспитывать поступивших в семинарию осетинских детей «в духе веры» [4, с. 112]. В автобиографии, откуда взята эта информация, Иуане умолчал лишь о том, как активно способствовал зачислению осетинских юношей в существовавшие тогда учебные заведения и как устраивал у себя тех из них, которым негде было остановиться [3, с. 22, 57]. Эту инициативу персонального покровительства соотчичам («ме 'мирон мыггагæн») в получении ими знаний позднее ревностно подхватит священник Аксо Колиев, открывший на свои средства в 1862 году начальную школу для осетинских девочек. А еще пару десятилетий спустя в отчаянную борьбу за существование первого на всем Северном Кавказе рассадника женского образования, переименованного к тому времени в Ольгинское трехклассное училище, вступят лучшие представители осетинской интеллигенции во главе с Коста Хетагуровым и отстоят его ценою обрушившихся на них тяжких репрессий [14, с. 14-18].

Еще одной благодатной традицией, заложенной Ялгузидзе в годы преподавания в семинарии стало его «отношение к переводческой и просветительской работе как к серьезному и важному делу, имеющему культурное значение» [6, с. 284].

Создание алфавита, букваря. Как известно, первоочередными задачами на начальном этапе просветительского движения на Северном Кавказе были вопросы формирования письменности на родном языке. За время преподавательской деятельности И. Ялгузидзе интенсивно занимался разработкой системы графических знаков для передачи осетинской речи, одновременно внедрив в осетинскую среду два фрункционально различных алфравита, оба на основе грузинской графики: 1) с опорой на церковную азбуку хуцури, 2) на знаки грузинского светского письма; он выступил также составителем первого букваря (1821). «Умным» и «почтенным» осетином назвал его академик А. Шегрен при оценке алфравита, который в определенной степени послужил ученому подспорьем при написании его «Осетинской грамматики» [15, с. 27-28]. У адыгов примерно в это же время первую попытку по составлению азбуки на основе арабской графики предпринял Нотаук Шеретлук (Магомет Эфенди). Чуть позже Шора Ногмовым дважды разрабатывался кабардинский алфавит (в 1825 г. на основе арабской, в 1830 г. - на основе русской графики). В 1853 г. был издан «Букварь черкесского языка» У. Х. Берсея.

Вот вкратце то, что касается просветительскопедагогической стези И. Габараева-Ялгузидзе. Заметим, что деятельность адыгских просветителей первой волны - С. Хан-Гирея (1808-1842), Ш. Ногмова (1794-1844) и др., хотя бы в силу их возраста, начиналась значительно позже.

Переводческая деятельность. Надо сказать, к созданию осетинской письменности Иуане приступил еще в дни своей переводческой практи- ки, т. е. значительно раньше указанной выше даты. В рапорте генерал-майора Кнорринга от 26 марта 1802 года сказано, что дворянин Иван Ялгузидзе, «который будучи родом осетинец», был посылаем неоднократно русскими властями «к увещанию неблагонамеренных своих соотчичей и исполнял препорученное с желанным успехом, переводил учреждения временных судов и присяги с грузинского на осетинский диалект, для чего заимствовал литеры грузинские (выделено мною. - М.И.), чего еще здесь не бывало, поелику осетинцы знаков для изображения слов своего языка не имеют» [10, т. 1, c. 587]. Небольшая рукопись (3 страницы) одного из его переводов весной 1926 г. нашлась в фрондах грузинского просветительского общества. В ней говорится о создании для закавказских осетин суда в Цалагоме, в селении Уанат. В 1927 г. В. И. Абаев опубликовал этот текст в журнале «Фидиуæг» [16, с. 54-56]. Переложение на осетинский язык «положения о временных судах и присяге»(«Учреждения суда для осетинцев, расположенных в уезде Арагвы и у р. Малой Лиахвы») считается первым печатным изданием светского направления в Осетии.

За усердный труд в деле мирного вхождения соотечественников в русское подданство И. Ялгузидзе была пожалована золотая медаль на алой шелковой ленте (1802 г.) [10, т. 1, с. 587]. 6 мая 1815 года он поступил на службу в Осетинскую духовную комиссию. Трехлетняя плодотворная миссионерская деятельность на этом поприще увенчалась присвоением Иуане чина губернского секретаря и награждением его орденом св. Анны [3, с. 42]. Тогда же экзарх Грузии Феофилакт предложил ему заняться переводами богослужебных текстов, которые в большинстве своем были впоследствии опубликованы: «Утренние и вечерние молитвы», «Катехизис с кратким христианским нравоучением» - одной книгой в Тифлисе в 1820 г.; через год Божественная литургия - в Москве; там же в 1824 г. «Последование священного крещения, обручения, венчания и погребения» [17, с. 639].

Среди переложений И. Габараева-Ялгузидзе церковной литературы на осетинский язык особое место занимает «Четвероевангелие», этот перевод в отличие от остальных осуществлен на базе грузинского светского письма. Почти все исследователи творчества Иуане сходятся на том, что рукопись с предисловием на осетинском и грузинском языках, с одобрения экзарха Грузии и Святейшего Синода, в 1823 году была отправлена в Петербург, однако издание ее по какой-то причине не осуществилось [6, с. 311; 9, с. 286 и пр.]. Но есть и другая информация: Четвероевангелие в переводе Ялгузидзе было издано комитетом Российского Библейского общества в Москве в количестве 2.000 экз., которые были разосланы по церквям Осетии [18, с. 86]. Профрессор Б.В. Скитский также был уверен, что рукопись увидела свет, но уже после смерти И. Ялгузидзе в Москве, в 1841 году [19, с. 185]. Аргументом в пользу данного предположения может стать и нижеприводимый текстовый фррагмент в прошении вдовы Иуане, Марии Ялгузидзе, к главнокоман- 
дующему Грузией И.Ф. Паскевичу-Эриванскому о назначении ей пенсии по смерти мужа: «Между тем найдя начальство его способным приказало перевести с грузинского на осетинский язык Евангелие, что и исполнил со всею рачительностью, по которой идет теперь у них святое служение» [9, с. 289] (выделено мною. - М.И.) Доверять ли печатному слову прошлых веков или довольствоваться фрормулировкой «по неизвестной причине»? - вопрос остается открытым.

Переводы И. Ялгузидзе богослужебных текстов с грузинского на осетинский язык, помимо миссионерских целей, сыграли определенную роль в становлении осетинской прозы [20, с. 175]. И даже в упомянутых выше служебных рапортах или в таком сугубо деловом документе, как Положение о Ванатском суде, исследователи видят наличие субъективных интенций автора [20, с. 169]. Не кажутся преувеличением слова выпускника Московской духовной академии и Дипломатической академии МИД РФ, кандидата богословия о. Саввы (М. Гаглоева), который полагает, что переводы «Божественной литургии святителя Иоанна Златоуста и Святого Евангелия, а также разработка осетинского алфавита являются главной заслугой Ялгузидзе перед осетинской культурой и делают его просветительскую деятельность сродни подвигу святых равноапостольных братьев Кирилла и Мефодия» [Цит. по: 3, с. 48]

Автобиографический нарратив. Личностный аспект еще заметней в описании осетинским просветителем истории собственной жизни, которая предстает как процесс, развивающийся на пересечении «линий социализации и индивидуализации». «Труд, усердие и верность долгу - вот три императива, которые, судя по переводной версии автобиографии Ялгузидзе, фрормировали его личность» [13, с. 105]. Предисловие к переводу Евангелия (1820-1823), как уже говорилось, написано на родном языке. В нем автор формулирует цель своей жизни и цель жизни каждого члена общества - послужить отечеству в меру сил и возможностей. По мнению исследователей, в небольшом по объему тексте содержится целостная просветительская и общественно значимая программа развития народа, в которой в одном ряду расположены два судьбоносных понятия: мыггаг (в знач. 'нация как высшая фрорма этноса') и чиныट (книга). Убежденность в том, что человек без света знания ущербен и обделен, выливается в поэтически вдохновенные строки: «...æмæ гæзæмæ байгом сты ме 'нахъомыл зæрдæйы цæстытæ <...> базыдтон ай, æмæ мыггаг, кæмæн нæй чиныг, уый хъаджджын у раст æмбарынæй; нæ зоны аккагау Хуыцауы æмæ нæдæр йæхи» $[7$, с. 98] - «...чуть приоткрылись очи моего отроческого сердца <...> и узнал я, что народ, у которого нет книги, лишен истины, не знает порядком ни Бога, ни самого себя». (Здесь и далее цит. по переводу Н. Джусойты. - М.И.) То есть без книги человек не в состоянии понять и принять Слово Божье, но он не способен также осознать и свои корни, свое национальное «Я». Существо же без роду и племени - это, как известно, «раб и лакей» [21]. И далее следует рассказ разумного и верного сына своего народа, Иуане, о том, как он «осмелился, наконец, создать книгу на осетинском языке», потрудившись над нею «три года денно и нощно»: «Афтæ мæ хъомыс цас уыди, мæхиуыл нæ бацауæрстон, цæмæн сымах, ме 'миронтæ, ма фææуат хъаджджын ацы стыр хъуыддагæй» [7, с. 99] - «И сколько было в моей воле, не щадил себя, чтобы вы, мои единокровные осетины, не были лишены этого великого блага». Как верно заметил В. Уарзиати, в предисловии к Евангелию сквозь религиозно-философское содержание проступает «мощь осетинского духа того времени, и мы ощущаем в ней тоску народа по книге» [4, с. 115]. Эмоциональная одухотворенность слова в этой предтече осетинской художественной мысли позволяет характеризовать ее как «патриотическое духовное завещание» автора и одновременно - как исповедь перед родным народом [22, с. 55]; как «гимн книге, интеллекту, труду» [20, с. 173], т. е. просветительским заповедям начала XIX века.

Пройдет время, и такую же обеспокоенность будущим своего народа выскажет Хан-Гирей в «Записках о Черкесии» (1836), горько сетуя на то, что адыги «на собственном языке не имеют книг, ибо лишены лучшего приобретения человеческого разума - письмен», вследствие чего многие события черкесской истории искажены «обманчивым эхом темных преданий». И подытожит: «Такова жалкая участь народов непросвещенных: их бытие и дела проходят безмолвно и теряются во мгле забвения» [23, с. 137$]$.

В свое время автора этих строк поразило сходство предисловия Иуане Габараева-Ялгузидзе к Евангелию и вступительного слова Шоры Ногмова к «Начальным правилам адыхейской грамматики» (1840), в котором озвучивалась мотивация его многолетнего труда: «С того времени, как я узнал, что каждый народ, сколько-нибудь образованный, имеет науку о своем языке, известную под именем грамматики, я стал ревностно заниматься своим адыхейским языком...» [24, с. 107]. Будучи уверена в том, что кабардинский автор не мог быть знаком с осетинским текстом Ялгузидзе, я писала в одной из своих статей: «Единство интонационного звучания авторского слова, факты текстуально-смысловых совпадений в трудах, создаваемых в разное время и на разных языках, даже при абсолютном тождестве идей, их фрормирующих, очевидно, требуют своего осмысления» [13, с. 106]. Ответ вскоре нашелся вместе с информацией о том, что рукопись Ялгузидзе была обнаружена К. Г. Залеманом среди бумаг в архиве акад. А. Шегрена [4, с. 114].

Ш. Ногмов был знаком с Шегреном с 1835 года и в дальнейшем поддерживал с ним тесные дружеские связи. Даже посвятил ему и русской науке «Хох» (здравицу). В своем письме от 12 апреля 1837 года в Академию наук ученый сообщал, например, что в феврале Ногмов пробыл его гостем «две полные недели, в продолжение которых они занимались разборами вопросов грамматики и дру- 
гих лингвистических проблем» [25, с. 23]. Известно также, что Ногмов несколько раз посылал рукопись «Начальные правила адыхейской грамматики» Шегрену, и тот высказывал ему замечания и даже несмотря на дружбу, два раза не рекомендовал рукопись к изданию. Аргументация была следующая: данная работа «полезна только тому, кто умеет ею критически пользоваться как материалом к исследованию грамматического устройства чудного и трудного кабардинского языка» [25, с. 24]. Из сказанного с большой долей вероятности следует, что Шегрен в процессе «разбора вопросов грамматики» с Ногмовым рекомендовал тому в качестве образца стилистику и идейно-духовную направленность текста Предисловия И. Ялгузидзе как носителя новых ценностных ориентаций.

Литературная деятельность. Просветительская литература в северокавказском регионе на первых порах создавалась на русском языке. Особенность же творчества И. Ялгузидзе заключается в синтезе различных культурных традиций. Переводы церковных книг осуществлялись им с русского и грузинского языков, предисловие к Евангелию писалось на осетинском языке, служебные доклады и литературные произведения, дошедшие до нас, - на грузинском. Среди последних - два стихотворения «ямбики», опубликованные Т. Рухадзе в 1939 г. в его книге «Грузинский эпос в литературе “переходного периода"» [26, с. 245]. Невероятная путаница в атрибуции адресата этих «ямбиков», демонстрируемая в наши дни «осетинской стороной», порождает некий «инцестуозный крен». Княжна Кетеван, которой посвящены стихи, то обретает статус невесты царского сына («паддзахы фрырты усаг») и здесь же, чуть ниже - невесты царя [27], то она - и вовсе царица [3, с. 59], в ранг же ее венценосного супруга возведен сын Григорий.

А что говорит об этом историческая хроника? Григол (Григорий) (1789-1830) - правнук Ираклия II и внук последнего грузинского царя Георгия XII, единственный наследник князя Иоанна Георгиевича Багратиони (1768-1830) и Кетеван (урождённой княжны Церетели) (1775-1832). Смотрим далее: из начальных букв первого из ямбов, по форме пятистрофного акростиха, складывается пожелание: «Мепис сдзали Кетеван небас ецъиос», прочитанное в ряде работ как «Пусть сбудутся мечты царицы Кетеван». Можно, конечно, предположить, что автор употребил подобное обращение в переносном смысле: как восхваление той, которая превосходит всех в уме, красоте, кротком нраве или в чем-либо еще. Или, допустим, как посвящение властительнице дум поэта. Но насколько корректно это по отношению к представительнице правящей династии, матери его воспитанника?

К счастью, в подобного рода гипотезах нет необходимости. Еще в 1957 году Дз. А. Гугкаев внес ясность и в процесс установления адресата стихотворений, и в интерпретацию их содержания. Начнем с того, что упомянутые стихи ни в каком государевом «фонде» (тем более несуществующего царя!) обнаружены не были, а сохранились в рукописном фолианте Григория, сына царевича Иоанна, и посвящены его матери, Кетеван Зурабовне Церетели, «передовой в свое время женщине, оставившей о себе память в грузинской литературе» [26, с. 245]. По описанию Дз. А. Гугкаева, в указанном фолианте присутствуют тексты различных авторов; стихи нашего соотечественника расположены в рукописном сборнике друг за другом и снабжены припиской: «Ямбы, преподнесенные в дар учителем Григория, сына грузинского царевича Иоанна, воспитанником Иоанна Цилкнели, Иоанном Ялгузидзе, светлейшей невестке царя всей Грузии (выделено нами. - М. И.) Кетеван Зурабовне Церетели в день ее рождения, совпадавший с днем Рождества Христова», где под Иоанном Цилкнели разумеется И. Карумидзе, надо полагать, ввиду возведения его в сан епископа Цилканской епархии. Кетеван же «светлейшая невестка» царя Георгия XII.

Дз. А. Гугкаев акцентирует внимание читателя на хорошем владении Иуане техникой стихосложения: в каждой из пяти строф акростиха по пять нерифмованных строк, в строке - 12 слогов, поделенных цезурой на две части - по пять и семь слогов соответственно [26, с. 245]. Оба стихотворения даны в подстрочном переводе и уточнениях В.Д. Дондуа (в круглых скобках - буквальное следование оригиналу, в квадратных - смысловые уточнения). Корректно анализируется мотивация И. Ялгузидзе к их написанию: по мнению исследователя, автор «был в близких отношениях с семьей царевича Иоанна Георгиевича и, по-видимому, пользовался уважением и гостеприимством Кетеваны» [26, с. 246]. Чтобы предупредить дальнейшее репродуцирование несуразностей в толковании «ямбиков», считаем целесообразным привести здесь переводные тексты в полном объеме.

Побудила («привела») меня мысль великая («желанная»), -

Ибо соответствует это сегодняшнему («этому») [торжественному] дню, -

Взлететь в мир идей, [взмахнув] мощными («достойными») крыльями.

Стремится к этому и разум неучей,

Дабы выразить радость («признаки радости»). II.

Бог Слово, к нам сошедший с неба,

Силы зла полностью низвергает.

Потому хочу я усилить свой слабый голос,

Да будет лев, вышедший изо рта Иуды ${ }^{4}$,

Заключать в себе Ваши совершенства.

III.

Подобно тому, как Рождество Христово утешило всех,

Пусть и Вас утешит росою милости [Всевышний],

${ }^{4}$ Здесь сравнение Христа с Иудой из колена Давидова (Молодой лев Иуда, с добычи, сын мой, поднимается. Преклонился он, лег, как лев и как львица: кто поднимет его? (Быт. 49, 9; Числ.24,9; 1 Пар.5,2). 
Вместе с Вашим единоплотным, светлейшим [князем Григорием],

[Вселив в Вас] силу воли для истребления супостатов («двоедушных»),

Чтобы увидеть нам сообразное с родовитостью возвышение Вашего сына. IV.

Вас, невредимых под защитой сонма ангелов, Во исполнение Ваших желаний,

Он, умудряющий мудрых, изгоняющий злых,

В сей знаменательный, истинно божественный день,

Да преисполнит радостью на многие годы.

$$
\text { V. }
$$

Сии неискусные («малые») ямбики

(«глас, звуки»),- мой посильный труд,

Выражающие [мои] благожелания, [стихи,] хоть и неудачные («неказистые»),

Плод вдохновившей меня возвышенной

(«должной, соответствующей») мысли, Здесь и в потустороннем мире

(«в двойной жизни»), покорным воле божьей,

Вашей особе и всем Вашим

да будет дарована жизнь [радостная].

Второй текст состоит из пяти строк и представляет собой славословие в честь рождения Христа в «пещере малой» (в Вифлееме). Особенностью его являются временна̀я анафора, прием уподобления земного небесному, взаимосвязанность библейской истории с космическими ритмами бытия:

В сей день тайная, чудесная и величавая,

В сей день пещера малая небесам

уподобляется,

В сей день пресвятая дева «херувимствует»,

В сей день ясли принимают вид вселенной,

Да будет он величественен, ради нас

явленный отрок.

Дз. А. Гугкаев, первоначально считавший, что Ялгузидзе «написал ряд стихотворений на грузинском языке» после того, как оставил преподавательскую деятельность в семинарии (1922) [6, с. 285], впоследствии «сдвинул» хронологию их создания до первого десятилетия XIX в., когда Иуане «был учителем Григория, сына царевича Иоанна». Поскольку в предпосланной стихам приписке говорится о «царской невестке», мы, в свою очередь, склонны считать, что ямбики возникли на исходе XVIII века, в недолгий период правления Георгия XII (11 янв. 1798 г. - 28 дек. 1800 г. $)^{5}$. С его смертью произошло упразднение монархии в Картли-Кахетии, и Российская империя стала депортировать членов царской семьи вглубь России. Князь Иоанн Георгиевич в 1803 г. поселился в Санкт-Петербурге, Кетеван же с сыном остались в родовом имении Церетели в Имеретии. С учетом сказанного и в соотнесении с фактами биографии самого Иуане, полагаем, что гувернером Григола он мог быть в отрезок времени между окончанием обучения в Давидо-Гареджийской пу́стыни (1793 г.) и началом учительства в Душети, ошибочно исчисляемым непосредственно с даты смерти Ираклия II. По логике вещей, Иуане в 1799 году все еще оставался гувернером Григория; последнему исполнилось к этому моменту 14 лет.

Можно с уверенностью разделить мнение части биографов И. Габараева-Ялгузидзе, которые утверждают, что его поэтический талант не исчерпывается рассмотренными выше «ямбиками». Хочется надеяться, что волею провидения осетинскому читателю еще откроются новые стихотворные тексты мастера.

Проблема датировки ямбических посвящений выводит нас к другому произведению автора, тоже созданному на грузинском языке, - «Поэме об Алгузе». Не углубляясь в подробности споров об ее авторстве и времени написания, сошлемся на аргументацию Н. Джусойты. Обобщив имеющиеся мнения, ученый доказательно, как нам кажется, разделил точку зрения профрессора К. Кекелидзе, утверждая, что поэма могла быть создана не позднее конца XVIII века, поскольку в ней «идеал политического устройства Осетии мыслится автору в форме феодальной государственности» [22, с. 52], а уже последующая деятельность Ялгузидзе, как явствует в том числе и из проведенного нами обзора, связана с эволюцией его идейных воззрений, т. е. с усвоением просветительских взглядов на развитие общества. В задачи данной статьи не входит также развернутый анализ художественного текста, тем более что это с успехом осуществлено в трудах знатоков словесности, начиная с. Вс. Миллера, Г. Баева и заканчивая А. Тибиловым, Дз. Гугкаевым, Г. Бестауты и Н. Джусойты. Заметим только, что «Поэма...», хоть и выкроена она по жанровым лекалам рыцарского романа, с использованием качественно иных принципов и способов миромоделирования, тем не менее по своему идейному пафосу и ряду других показателей созвучна ранним образцам просветительской литературы региона и, на наш взгляд, вполне может считаться их предвестником. Сближает поэму с научно-художественными просветительскими текстами и романтизация исторического прошлого.

Исследователи сходятся в том, что поэт-патриот И. Ялгузидзе, прославляя подвиги Алгуза и возводя его родословную к династии греческих царей, с одной стороны, апеллировал к национальному самосознанию осетин, с другой - намеревался вызвать интерес и почтительное отношение к своему народу, к его истории у других этносов. Аналогичными мотивами был движим впоследствии и Ш. Ногмов, мифрологизируя этногенез адыгов и выводя легендарных антов в качестве их первопредков. Еще одна точка соприкосновения с северокавказскими просветительскими нарративами, это - этнографизм. В «Поэме...» не нужно искать реальной исторической основы. «Но в ней с замечательной точностью описаны существующие и поныне или до

${ }_{5}^{5}$ Тот фракт, что стихи написаны ко дню рождения Кетеван, совпадавшему с днем Рождества Христова, позволяет еще сузить датировку, сводя ее к 25 декабря 1799 г. 
недавнего времени традиции осетин. Такие, например, как похищение невесты, похоронные ритуалы, слова надгробных рыданий; торжества по случаю рождения сына; обычаи гостеприимства, кровной мести, примирения врагов за "трапезой мира", почтения и уважения к женщине, к праху врага, в обязательном порядке надлежащего выдаче близким для погребения и мн. др. Все это, а также яркие сцены сражений, выполненные в лучших традициях героического эпоса, создают художественную атмосферу и осетинский колорит произведения, работают на "национальную идею"» [13, с. 104].

Выше мы озвучили собственную гипотезу касательно истоков литературных штудий Ялгузидзе. Но если даже придерживаться мнения той части исследователей, которые относят написание стихов-посвящений, а также «Поэмы об Алгузе» ко времени прекращения автором педагогической деятельности (1822 г.), то и тогда осетин Иуане Габараев проявил себя как творческая индивидуальность на полтора десятка лет раньше, чем зародилась русскоязычная проза адыгских просветителей (как известно, первые публикации - «Долина Ажитугай» и «Персидский анекдот» С. Казы-Гирея - состоялись в 1836 г. в пушкинском «Современнике».)

Исходя из вышесказанного, И. Габараева-Ялгузидзе можно по праву назвать провозвестником северокавказского просветительства интегрировавшим в себе множество граней этого движения: религиозную, миротворческую, педагогическую, переводческую, литературноэстетическую. Кто знает, какими художественными открытиями одарил бы он еще нас, если бы смерть не настигла его в расцвете творческих сил?! Иван Георгиевич умер от холерной эпидемии 5 августа 1830 года.

Рассказ о жизни и творчестве осетинского просветителя уместно завершить словами В. Уарзиати, справедливо считавшего, что с появлением книги осетины «решительно устремились в прогрессивную европейскую культурную среду», и призывавшего помнить светлое имя того, кто стоял у истоков этого удивительного события, «поклоняться ему, словно открывшемуся нам божеству» [4, с. 118]. Воистину велика заслуга Иуане перед нами, его соотечественниками, поскольку он «был первым, кто из бескнижной тьмы начал прокладывать своему бедному народу широкую дорогу в свет христианского мира, к образованию и знаниям» [4, с. 118].

Но зададимся вопросом: как мы обращаемся с именем человека, просветителя, которого В. Уарзиаты призывал почитать как святого? На фоне отмеченных пробелов в изучении жизни и творче- ства И. Ялгузидзе отторжение вызывает в публикациях последних лет некритическое тиражирование фактов и сведений, введенных в научный оборот еще в 1930-1950-х гг. Г. Бочоридзе, 3.Н. Ванеевым, Дз.А. Гугкаевым и другими его биографами, а то и откровенное - с «легкой редактурой» - заимствование материала чужих исследований. Так, в монографии Р.Я. Фидаровой с весьма солидным названием «Осетинский литературный процесс. Проблемы истории и теории» - без ссылок на первоисточники - дважды (?) репродуцируется мифо о формировании мировоззрения и эстетических взглядов И. Ялгузидзе в период пребывания его «при дворе грузинских царей Ираклия и Георгия» [28, с. 18, 100]. Некорректное использование чужого текста оборачивается далее новыми курьезами. Такими, например, как своеобразный монтаж персонажей («два в одном») «Поэмы об Алгузе» - Кесар-хана, отца Эстерь, и чеченского царя Кайрана - с соответствующим искажением в пересказе исследователя событийной канвы произведения [28, с. 97]. Искажен (и тоже в двукратном повторе!) даже программный текст просветителя. Усечение идиомы («народ, не имеющий книги [...], не знает как следует самого себя» $[28,17$, 97]) - это не остаточная ли, часом, инерция оглядки на официозный атеизм советских времен? Еще один неприятный аспект связан с указанием на то, что просветительский текст цитируется якобы по книге Н. Джусойты. То есть замеченная погрешность автоматически «приписывается» известному ученому; возможность же убедиться в обратном, ввиду неточности ссылки, весьма затруднена. Но это еще не все. Апофеозом безосновательности является утверждение автора, что Ялгузидзе получил образование, наряду с просветителями его времени, «в российских учебных заведениях» [28, с. 19].

В заключение еще одна выдержка, из диссертации, защищенной во Владикавказе. Автор - Г.С. Кубанцева: «Первые просветители - адыги С. Казы-Гирей, Ш. Ногмов, осетины А. Колиев, Г. Токаев, И. Ялгузидзе и другие изучают национальную историю, создают алфавиты горских языков, первые литературные произведения» [29, с. 3]. Обратим внимание на перечислительный ряд, в котором И. Ялгузидзе отводится вместо первого последнее место, и это при отсутствии каких бы то ни было - хронологического, алфавитного, сравнительного либо иного - принципов называния.

Исследования подобного рода множатся, а «белые пятна» в биографии и творческом пути замечательного сына Осетии остаются. Однако такой ли памяти достойны святые имена нашей истории?!.

\section{ЛИТЕРАТУРА}

1. Акавов 3.Н. Просветительство и развитие дооктябрьской литературы тюркоязычных народов Северного Кавказа : Авторефр. дис ... д-ра фрилол. наук. - Алма-Ата, 1988. 40 с. 2. Хатаев Е.E. Просветители горских народов XIX века: Учебное пособие. - Орджоникидзе: Изд-во СОГУ, 1985. 86 с

3. Чибиров Л.А. У истоков осетинского просвещения: Иуане Габараев-Ялгузидзе. - Владикавказ: АО «Осетия Полиграфрервис», 2016. 182 c.

4. Уарзиаты В. Чырыстон тæваг ирон удварны // Мах дуг,
1995. № 11-12. C. 102-118.

5. Salemann Carl. Die Sjogrenschen Handschriften // Melanges Asiatiques. T. X, livr. 2. St.-Ptg. C. 283-284.

6. Гугкаев Дз. А. О жизни и деятельности Ивана Ялгузидзе // Известия ЮОНИИ. Вып. VII, 1955. С. 278-323.

7. Ахвледиани Г. АЕъъуызаты Иуанейы алыфрарс // Фидиуæе. 1928. № 2. С. 97-99.

8. Е. К. Краткий очерк истории грузинской церкви и экзархата за ХIX столетие. - Тифрлис, 1901. 
9. Бочоридзе Г. Иван Ялгузидзе (Материалы для биографрии) // Известия ЮОНИИ. Вып. III. 1936. С. 279-297.

10. Акты, собранные Кавказской археографической комиссией. - Тифрлис. T. I. 1866.827 с.; T. VII.1878. 1011 c.

11. Джусойты Н. Дыууæ ффæндиаджы // Рæстдзинад. 1998. 16 май. 12. Оразаев Г.М. Тюркоязычная деловая переписка на Северном Кавказе XVII-XIX вв. - Махачкала, 2007. 322 с.

13. Мамиева И.В. Авторское "я» в текстах северокавказских просветителей кониа XVIII - начала XIX века // Вестник Дагестанского научного центра РАН. - Махачкала, 2013, № 50. С. 103-109.

14. Кусаева З.К. Художественный опыт К.Л. Хетагурова-драматурга. - Владикавказ: ИПО СОИГСИ ВНЦ РАН, 2009. 222 с.

15. Шегрен А.М. Осетинская грамматика с кратким словарем. - СПб., 1844. [Репринт 2011 2.].

16. Абайты У. Ногссаргæ рагон ирон къухфыст // Фидиуæа, 2007. № 1-2. С. 52-57.

17. История Юго-Осетии в документах и материалах (18001864 ге.). Т. ІІ. - Сталинир: Госиздат Юго-Осетии, 1960. 738 с. 18. Обзор деятельности Общества восстановления право славного христианства на Кавказе за 1860-1910 ге. - Тифрлис: Тип. Кани. Наместн. Е. И. В. на Кавказе, 1910. 232 с.

19. Скитский Б.В. Очерки по истории осетинского народа с древнейших времен до 1867 г. // Изв. СОНИИ. Т. ХІ. - Дзауджи кау: Севосгиз, 1947. 215
20. Салагаева 3.M. От Нузальской надписи к роману: Проблемы генезиса и становления осетинской прозы. - Орджоники дзе: Иp, 1984. 312 c

21. Джыккайты Ш. Чиныट æмæ адæмы хъысмæm // Рæстдзинад. 1998. 6 июнь.

22. Джусойты Н.Г. История осетинской литературы: Дооктябрьский период. Кн. I (ХІХ век). - Тбилиси: Мецниереба, 1980 332 c.

23. Хан-Гирей. Записки о Черкесии. - Нальчик: Эль-Фа, 2008. $264 c$

24. Ногма Ш.Б. Филологические труды. Т. 2. - Нальчик: Каб.Балк. кн. изд-во, 1958. 200 с.

25. Ногмов Ш.Б. История адыхейского народа, составленная по преданиям кабардинцев. - Нальчик: «Эльбрус», 1994. 232 с.

26. Гугкаев Дз.А. Произведения Ивана Ялгузидзе // Известия ЮОНИИ. - Сталинир, 1957. Вып. VIII. C. 245-254.

27. Калоты Г. Рухстауæа // Рæстдзинад. 1990. апрель.

28. Фидарова Р.Я. Осетинский литературный процесс. Проблемы истории и теории: В 5-ти т. T. 2 - Владикавказ: СОИГСИ ВНЦ РАН, 2017. 309 c

29. Кубанцева Г.С. Научно-педагогическая и просветительская деятельность адыгских просветителей второго поколения в Северо-Кавказском регионе: Дис. ... канд. пед. наук. - Владикавказ, 2003. 136 c

\title{
IVAN YALGUZIDZE (IUANE GABARAEV) - THE FORERUNNER OF THE MOUNTAIN EDUCATION
}

\section{I.V. Mamieva}

$\mathrm{PhD}$, Associate Professor. North Ossetian Institute for humanitarian and social research by named after V.I. Abaev, Vladikavkaz scientific center of the RAS.

\begin{abstract}
The article examines the stages and aspects of the personal and creative formation of I. Gabaraev (Yalguzidze), a prominent Ossetian figure of the end of the late 18th - the first third of the 19th century, with the aim of consistently substantiating the fact of his pioneering in the most important spheres of the enlightenment movement in the North Caucasus. A number of discrepancies in his biographical information are noted, some corrections and clarifications are introduced. An analysis of the body of educational texts corpus is presented, in which a special emphasis is placed on the autobiographical narrative as a set of imperatives that form the type of enlightenment personality.

Keywords: I. Gabaraev-Yalguzidze, educator, teacher, Orthodox missionary, translated literature, business documentary, writing, autobiographical narrative, element of artistry, national identity.
\end{abstract}

\section{REFERENCES}

1. Akavov Z. N. Prosvetitel'stvo i razvitie dooktyabr'skoy literatury tyurkoyazychnykh narodov Severnogo Kavkaza : Avtoref. dis ... d-ra filol. nauk - Alma-Ata, 1988. 40 s.

2. Khataev E. E. Prosvetiteli gorskikh narodov XIX veka: Uchebnoe posobie. - Ordzhonikidze: Izd-vo SOGU, 1985. 86 s.

3. Chibirov L. A. U istokov osetinskogo prosveshcheniya: Iuane Gabaraev-Yalguzidze. - Vladikavkaz: AO "Osetiya Poligrafservis», 2016. $182 \mathrm{~s}$

4. Uarziaty V. Chyryston tævag iron udvarny // Makh dug, 1995. № 11-12. S. $102-118$

5. Salemann Carl. Die Sjogrenschen Handschriften // Melanges Asiatiques. T. X, livr. 2. St.-Ptg. S. 283-284.

6. Gugkaev Dz. A. O zhizni i deyatel'nosti Ivana Yalguzidze // Izvestiya YuONII. Vyp. VII, 1955. C. 278-323.

7. Akhvlediani G. AEg"uyzaty luaneyy alyfars // Fidiuæg. 1928. № 2 S. 97-99.

8. E. K. Kratkiy ocherk istorii gruzinskoy tserkvi i ekzarkhata za XIX stoletie. -Tiflis, 1901

9. Bochoridze G. Ivan Yalguzidze (Materialy dlya biografii) // Izvestiya YuONII. Vyp. III. 1936. S. 279-297.

10. Akty, sobrannye Kavkazskoy arkheograficheskoy komissiey. Tiflis. T. I. 1866. 827 s.; T. VII. 1878. 1011 s.

11. Dzhusoyty N. Dyuuæ fændiadzhy // Ræstdzinad. 1998. 16 may. 12. Orazaev G. M. Tyurkoyazychnaya delovaya perepiska na Severnom Kavkaze XVII-XIX vv. - Makhachkala, 2007. 322 s.

13. Mamieva I. V. Avtorskoe "ya» v tekstakh severokavkazskikh prosvetiteley kontsa XVIII - nachala XIX veka // Vestnik Dagestanskogo nauchnogo tsentra RAN. - Makhachkala, 2013, № 50. S. $103-109$.

14. Kusaeva Z. K. Khudozhestvennyy opyt K.L. Khetagurovadramaturga. - Vladikavkaz: IPO SOIGSI VNTS RAN, 2009. 222 s. 15. Shegren A.M. Osetinskaya grammatika s kratkim slovarem. SPb., 1844. [Reprint 2011 g.].
16. Abayty U. Nogssargæ ragon iron k"ukhfyst // Fidiuæg, 2007

№ 1-2. S. 52-57.

17. Istoriya Yugo-Osetii v dokumentakh i materialakh (1800-1864 gg.). T. II. - Stalinir: Gosizdat Yugo-Osetii, 1960. 738 s.

18. Obzor deyatel'nosti Obshchestva vosstanovleniya pravoslavnogo khristianstva na Kavkaze za 1860-1910 gg. - Tiflis: Tip. Kants. Namestn. E. I. V. na Kavkaze, 1910. 232 s.

19. Skitskiy B. V. Ocherki po istorii osetinskogo naroda s drevneyshikh vremen do 1867 g. // Izv. SONII. T. XI. - Dzaudzhikau: Sevosgiz, 1947. $215 \mathrm{~s}$.

20. Salagaeva Z. M. Ot Nuzal'skoy nadpisi k romanu: Problemy genezisa i stanovleniya osetinskoy prozy. - Ordzhonikidze: Ir, 1984 $312 \mathrm{~s}$

21. Dzhykkayty Sh. Chinyg æmæ adæmy kh"ysmæt // Ræstdzinad. 1998. 6 iyun'

22. Dzhusoyty N. G. Istoriya osetinskoy literatury: Dooktyabr'skiy period. Kn. I (XIX vek). - Tbilisi: Metsniereba, 1980. $332 \mathrm{~s}$.

23. Khan-Girey. Zapiski o Cherkesii. - Nal'chik: El'-Fa, 2008. 264 s.

24. Nogma Sh. B. Filologicheskie trudy. T. 2. - Nal'chik: Kab.-Balk kn. izd-vo, 1958. $200 \mathrm{~s}$

25. Nogmov Sh. B. Istoriya adykheyskogo naroda, sostavlennaya po predaniyam kabardintsev. - Nal'chik: "El'brus», 1994. 232 s.

26. Gugkaev Dz. A. Proizvedeniya Ivana Yalquzidze // Izvestiya YuONII. - Stalinir, 1957. Vyp. VIII. C. 245-254.

27. Kaloty G. Rukhstauæg // Ræstdzinad. 1990. aprel'.

28. Fidarova R. Ya. Osetinskiy literaturnyy protsess. Problemy istorii i teorii: V 5-ti t. T. 2. - Vladikavkaz: SOIGSI VNTS RAN, 2017. 309 s. 29. Kubantseva G.S. Nauchno-pedagogicheskaya i prosvetitel'skaya deyatel'nost' adygskikh prosvetiteley vtorogo pokoleniya v SeveroKavkazskom regione: Dis. ... kand. ped. nauk. - Vladikavkaz, 2003. $136 \mathrm{~s}$.

Kavkazskomregione: Dis. ... kand. ped. nauk. - Vladikavkaz, 2003. 136 s. 